\title{
Mating behavior in Atheloca subrufella Hulst, 1887 (Lepidoptera: Pyralidae:
} Phycitinae)

\section{Comportamento de acasalamento em Atheloca subrufella Hulst, 1887 (Lepidoptera: Pyralidae: Phycitinae)}

\author{
Abel Felipe de Oliveira Queiroz ${ }^{\mathbb{D}}{ }^{1}$, Jakeline Maria dos Santos $\mathbb{D}^{2}$, Mariana Oliveira Breda $\mathbb{D}^{3}$, Antônio \\ Euzébio Goulart Santana (iD 4
}

\begin{abstract}
${ }^{1}$ Doutor em Química e Biotecnologia, Universidade Federal de Alagoas, abelfelipi@gmail.com; ${ }^{2}$ Pós-doutoranda PNPD na Rede Nordeste de Biotecnologia, Universidade Federal de Alagoas, jackbilu@hotmail.com; ${ }^{3}$ Professora Doutora do Centro de Ciências Agrárias, Universidade Federal de Alagoas, breda.mariana@ hotmail.com; ${ }^{4}$ Professor Doutor do Centro de Ciências Agrárias, Universidade Federal de Alagoas, aegs@ ceca.ufal.br.
\end{abstract}

\section{A R T I G O}

Recebido: 09/03/2019

Aprovado: 16/05/2019

Key words:

Cocos nucifera

Coconut moth

Courtship behavior

Palavras-chave:

Cocos nucifera

Traça do coco

Comportamento de corte

\section{A B S T R A C T}

The mating behavior of the moth Atheloca subrufella Hulst, 1887 (Lepidoptera: Pyralidae) was investigated in laboratory arenas. The descriptions of courtship and copulation in males and females were based on direct observations of virgin couples. The courtship and copulation bioassays results comprise several behavior patterns such as antennation, female searching (walking and/or flying); female encounter; female calling behavior; exhibition of pheromone gland; male approach and copulation. For that, courtship and copulation behavior ethograms were presented. The results also suggest that the mating behavior in A. subrufella is mediated by a long-range pheromone and the presence of a short-range pheromone. In overall, this research presents itself as a basis study to further investigations upon A. subrufella sex pheromone and to improve the development of new strategies of behavioral control techniques.

\section{R E S U M O}

O comportamento de acasalamento da mariposa Atheloca subrufella Hulst, 1887 (Lepidoptera: Pyralidae) foi investigado em arenas de laboratório. As descrições de corte e cópula em machos e fêmeas foram baseadas em observações diretas de casais virgens. Os resultados dos bioensaios de corte e cópula compreendem diversos padrões comportamentais tais como, antenação, busca pela fêmea (caminhando e/ou voando), encontro da fêmea, comportamento de chamamento da fêmea, exibição da glândula de feromônio, tentativa de cópula e cópula. Para isso, foram apresentados etogramas comportamentais de corte e cópula. Os resultados também sugerem que o comportamento de acasalamento em A. subrufella é mediado por um feromônio de longa distância e pela presença de um feromônio de curta distância. De maneira geral, esta pesquisa apresenta-se como estudo base para futuras investigações sobre o feromônio sexual de $A$. subrufella e desenvolvimento de novas estratégias de controle comportamental.

\section{INTRODUCTION}

The study of mating behavior in insects is the first step for the development of sexual behavioral control strategies. Researches regarding calling behavior, presence or absence of pheromone gland, courtship and copulation patterns are being developed and stand as important tools to allow a better understanding and more accurate application of Lepidoptera control techniques (BARRADAS-JUAN et al., 2016; NASCIMENTO et al., 2016; SHI et al., 2018). According to Parra-Pedrazolli and Leal (2006), female moths produce a mixture of pheromone compounds and the complete bouquet is responsible for male attraction. Nevertheless, control by sex pheromone may be achieved by the use of a single major constituent or by the use of a partial mixture.

The coconut moth Atheloca subrufella (Hulst, 1887) [=Hyalospila ptychis (Dyar, 1919)] (Lepidoptera: Pyralidae) is an important coconut pests, presenting wide distribution in Brazil (FERREIRA et al. 2002), it was also reported in other countries such as the USA, Mexico, Cuba, and the Virgin Islands (BONDAR, 1940; HEINRICH, 1956; KIMBAL, 1965;

\section{Revista Verde}

ISSN 1981-8203

Pombal, Paraíba, Brasil v. 14, n.3, jul.-set, p.453-457, 2019

doi: $10.18378 /$ rvads.v14i3.6570

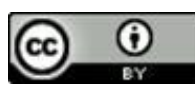


HABECK; NICKERSON, 1982; HODGES et al., 1983; MOORE, 2001). According to FAO (2017) Brazil is the world's fifth largest producer of coconuts, reaching approximately a production of 2.4 million of tonnes in an area of 108,629.00 ha.

The A. subrufella damage is performed by the caterpillars that develop inside of the coconut inflorescences and fruits, they feed on the mesocarp and blocking the flow of the sap. Infested fruits and inflorescences are aborted and those that do not fall from the coconut palm tree become deformed and commercially depreciated. The management of this pest by traditional methods is restricted to the collection of infested coconut fruits and the use of chemical insecticides (FONTES; FERREIRA, 2006). Nevertheless, these techniques are often hampered by the caterpillars endophytic habit consequently, studies of new and efficient control measures are required.

Behavioral control strategies is not used for A. subrufella. However, some studies were developed to describe biological aspects and calling behavior of this moth (BENTO et al., 2006; NASCIMENTO et al., 2016). In order to contribute as basis to the development of new behavioral management techniques, the objective of this study is to describe the courtship and copulation behavior of A. subrufella.

\section{MATERIAL AND METHODS}

\section{A. subrufella rearing}

The A. subrufella rearing was kept in the Natural Resources Research Laboratory of Federal University of Alagoas (LPQRN/UFAL) under laboratory conditions at $25 \pm 2$ ${ }^{\circ} \mathrm{C}, 80 \% \mathrm{RH}$ and photoperiod 14L: 10D. The insects were collected in the field, from coconut fruits with signs of infestation by $A$. subrufella caterpillars. The collections were performed in the states of Sergipe and Alagoas, Brazil. The coconut fruits were kept in plastic containers $(10 \mathrm{~L})$ covered with voile fabric until the caterpillars reached the pupal stage. Pupae were sexed and after adult emergence, couples were kept in plastic cages $(1 \mathrm{~L})$ lined inside with paper towel as oviposition substrate. Eggs were daily collected and kept in Petri dishes with moistened filter paper. The caterpillars were daily fed with mesocarp coconut fruit cube of $2 \times 2 \mathrm{~cm}$ until reached pupal stage.

\section{Courtship bioassays}

The courtship male behavior was direct observed through bioassays using a rectangular shaped glass arena $(20 \times 10 \times 15$ $\mathrm{cm}$ ) containing a female trapped in a cage (hair roller of $5 \mathrm{~cm}$ ) exhibiting calling behavior. The cage containing the female was covered by voile fabric to allow the compounds release and physical contact of male and female, but preventing the mating. Ten replicates were performed. For each replicate a different couple of adults was used. Four points were demarcated in the arena and in each replicate the female was allocated at a different point, aiming the elimination of any external physical, chemical or visual influence. A. subrufella adults with at least 24 hours age were used in the bioassays, ensuring sexual maturity (BENTO et al., 2006). The bioassays were performed from the first hour of scotophase, according to the period of $A$. subrufella female calling behavior (NASCIMENTO et al., 2016) under laboratory conditions of $25 \pm 2{ }^{\circ} \mathrm{C}$ and $60 \% \mathrm{RH}$. The couples were observed during $10 \mathrm{~min}$.

\section{Copulation behavior}

The copulation behavior was direct observed in plastic containers cages $(250 \mathrm{~mL})$ containing a virgin couple, the adults used in the bioassays were $24 \mathrm{~h}$ to $96 \mathrm{~h}$ of aged. Three replicates were performed. For each replicate a different couple of adults was used. The couple behavior was recorded during the female first scotophase period, according to the female calling behavior (NASCIMENTO et al., 2016). The description of the copulation behavior was performed through a video analyses made under red light conditions. The virgin couple was observed since the moment that the female exhibited the calling behavior until the moment of the copula.

\section{RESULTS AND DISCUSSION}

\section{Courtship bioassays}

During the arena bioassays was observed some behavioral patterns presented by A. subrufella adults. Both, males and females showed continuous antennation during courtship. The females performed the calling behavior throughout all the bioassay period. The male courtship behavioral patterns were classified as: antennation, female searching (walking and/or flying on the arena); female encounter; walking over the female cage surface, resting over the female cage surface; antennation on the female cage; mating attempt (flapping wings and arched abdomen); no mating attempt (Figure 1).

Figure 1. Courtship bioassays ethogram of Atheloca subrufella Hulst, 1887 (Lepidoptera: Pyralidae) $(n=10)$.

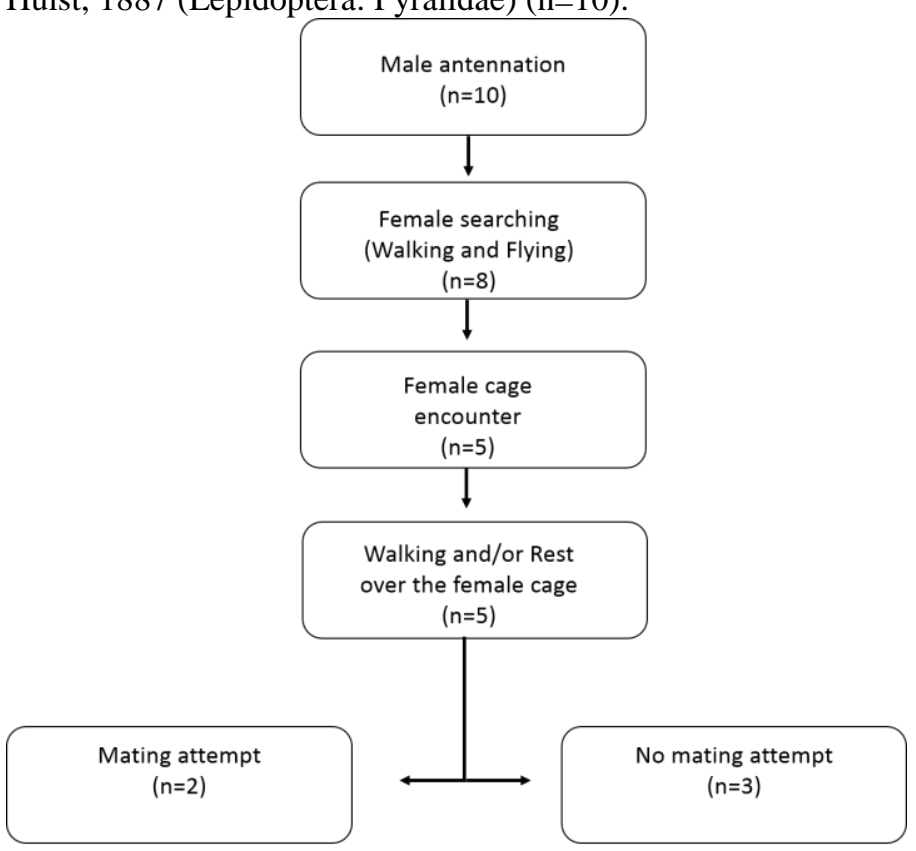

\section{Copulation behavior}

The copulation behavior patterns are described as follow: male and female presented antennation behavior; the female exhibited the calling behavior, with wings slightly apart exposing the pheromone gland at the final portion of the arched abdomen; the female rotated the final portion of the abdomen spinning the pheromone gland $360^{\circ}$; the male rotated its body $360^{\circ}$; the female rotated its body $360^{\circ}$ in both directions 
(clockwise and anticlockwise); the male approached the female; male and female showed antennation behavior facing each other and touching their antennae; the male lifted its wings exhibiting the hairpencil on the final portion of the abdomen; the male jumped over the female in a backflip resting on the ground with its abdomen opposite to the female abdomen; finally male and female initiated the copulation (Figure 2).

Figure 2. Mating behavior ethogram of Atheloca subrufella Hulst, 1887 (Lepidoptera: Pyralidae). Male and female antennation (A), female calling behavior (B, C), male and female body rotation (D, E), male and female touching antennae (F), male lifted its wings exhibiting the hairpencil $(\mathrm{G})$, male jumped over the female in a backflip resting on the ground with its abdomen opposite to the female abdomen $(\mathrm{H}, \mathrm{I})$, mating position $(\mathrm{J})$.
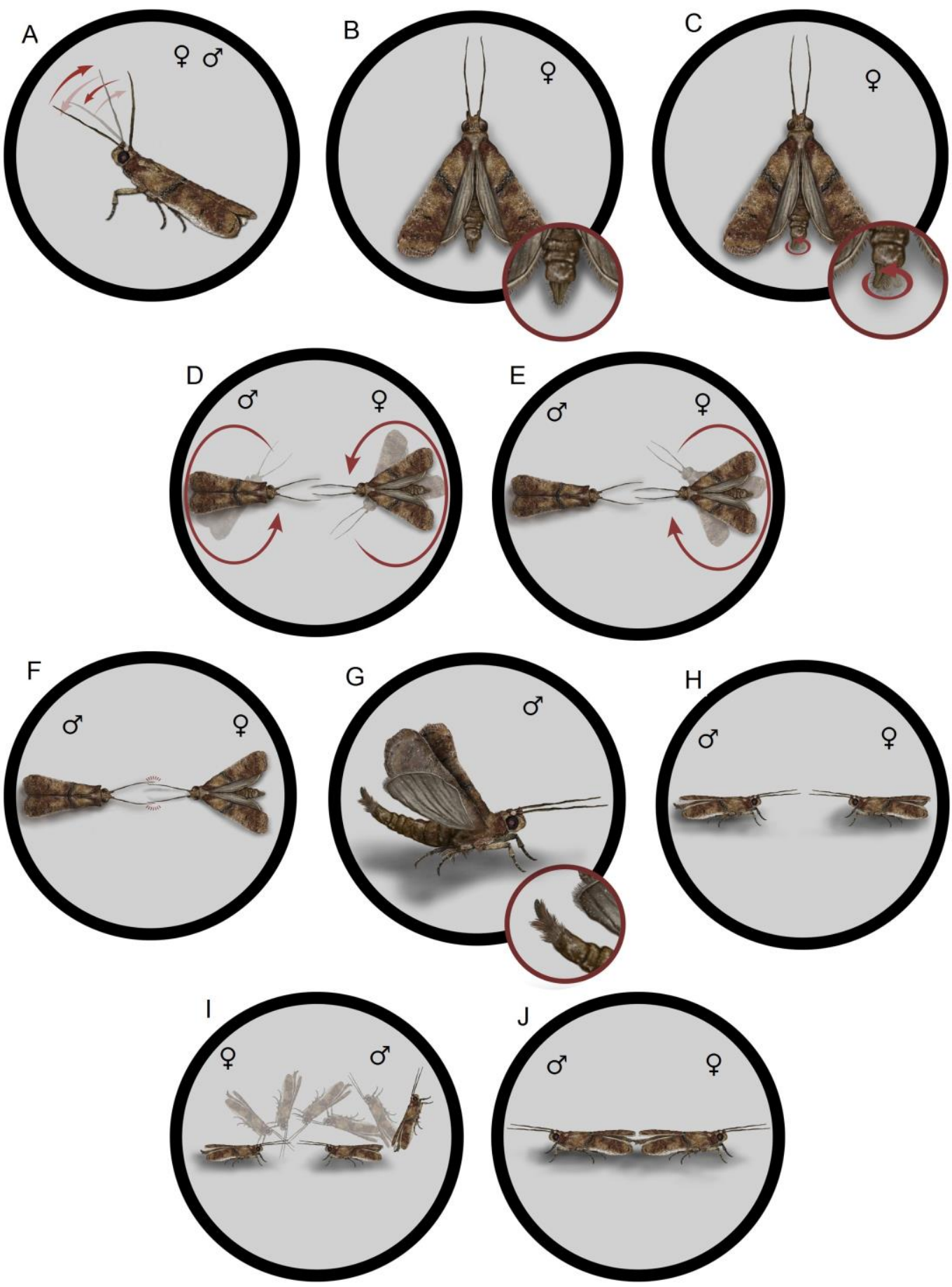
Based on the behavioral patterns showed by A. subrufella adults in the present study it is possible to assume that courtship and copulation in this species may be mediated by the presence of sex pheromone. A. subrufella females seems to release a long-range pheromone to attract the males, which recognize the females through contact, probably mediated by a short-range pheromone and/or cuticular hydrocarbons. This pattern of short distance recognition was also observed in other Pyralidae moth species, the Amyelois transitella Walker, 1863 (Lepidoptera: Pyralidae: Phycitinae), which exhibited similar behavior patterns such as antennation indicating a major characteristic of male and female sexual activity, the extrudation of a female abdominal (pheromone) gland and male recognition of female through antennation (PARRA-PEDRAZZOLI; LEAL 2006).

The Dioryctria abietella [Denis \& Schiffermüller], 1775 (Lepidoptera: Pyralidae: Phycitinae) also presented a very similar behavior to A. subrufella, such as the same pattern of female calling behavior; the behavior of the male and female of touching the antennae after assuming the frontal position; and the attempt of male copulation, where the male lifted its wings exhibiting the hairpencil on the final portion of the abdomen and jumped over the female in a backflip resting on the ground with its abdomen opposite to the female abdomen (FATZINGER; ASHER, 1971).

The results of the present study suggest that mating behavior in A. subrufella may be mediated by a primary mixture of compounds which acts as long-range sex pheromone and also by a secondary mixture of compounds which acts as a shortrange pheromone.

Same as that, the primary sex pheromone of Choristoneura fumiferana Clemens, 1865 (Lepidoptera: Tortricidae) is composed of (E)- and (Z)-11-tetradecenal, produced by the females and are efficient capturing virgin males on baited traps in a ratio 95: 5 (SANDERS and WEATHERSTON 1976; SILK et al., 1980). After cuticular compounds analyses, the presence of unsaturated alkanes in both sexes was noted, but the compounds (Z,Z,Z)-3,6,9tricosatriene and $(Z, Z, Z)-3,6,9$-pentacosatriene were identified only in females. Arena and wind tunnel bioassays using $C$. fumiferana adults showed that males exhibit patterns behavior as flapping wings and arched abdomen in the presence of female body parts extracts and the female unsaturated alkanes. In addition, two female cuticular compounds, (Z)-5-tricosene and $(Z, Z, Z)-3,6,9$-tricosatriene, enhanced male responses to the primary sex pheromone components, acting in the male orientation and short-range courtship. (SILK et al., 2017).

Among the subfamilies of Pyralidae, the Phycitinae is one of the most abundant, comprising about 5,000 species distributed throughout the world (LI; REN, 2009). However, only 35 female sex pheromones were identified in this subfamily. The pheromonal mixtures identified to the Phycitinae species are characterized by the presence of aldehydes, acetates, alcohols and hydrocarbons (ANDO; YAMAMOTO, 2018). The number of identified pheromones compared to the number of species in Phycitinae reinforces the requirement and importance of this study.

The use of sex pheromones as a behavioral control strategy offer an environmentally friendly practice, successfully applied in several techniques such as monitoring, mass control and mating disruption. Nevertheless, for A. srubufella, there is no sex pheromone identification until this moment and the control strategies are restricted to collection of infested coconut fruits and the use of chemical insecticides.

In overall, this research shows itself as a basis study to improve the development of new strategies of control, allowing further investigations upon A. subrufella sex pheromone, cuticular hydrocarbons and behavioral management techniques, within the principles of the Integrated Pest Management (IPM).

\section{CONCLUSIONS}

Based at the results of this research it is possible to conclude that in the mating behavior of A. subrufella, the female produces compounds to attract the male, and the male is responsible by the search, recognition of the female and attempted copulation. This knowledge is essential to apply techniques of population control using pheromone.

\section{ACKNOWLEDGEMENTS}

The authors would like to thank the research funding agency CAPES for the scholarships (protocol number: 1538957) granted to the post-graduate students participating in the study.

\section{REFERENCES}

ANDO, T.; YAMAMOTO, M. The List of Lepidopteran Sex Pheromones and Attractants. Internet Database, 2018. Available in: <https://lepipheromone.sakura.ne.jp/lepi_phero_list.html> Access in: 28 de Abril de 2019.

BARRADAS-JUANZ, N.; DÍAZ-FLEISCHER, F.; PÉREZSTAPLES, D. Mating Behavior of Hypsipyla grandella (Lepidoptera: Pyralidae) under Laboratory Conditions. Annals of the Entomological Society of America, v.109, n.3, p. 377383, 2016. 10.1093/aesa/saw001

BENTO, J. M.; NAVA, D. E.; CHAGAS, M. C. M.; COSTA, A. H.; LIBARDI, D. J.; PARRA, J. R. P. Biology and Mating Behavior of the Coconut Moth Atheloca subrufella (Lepidoptera: Phycitidae). Florida Entomologist, v.89, n.2, p. 199-203, $2006 . \quad \underline{10.1653 / 0015-}$ 4040(2006)89[199:BAMBOT]2.0.CO;2

BONDAR, G. Insetos nocivos e moléstias do coqueiro (Cocos nucifera L.) no Brasil. Salvador: Tipografia Naval, 1940. 156 p.

FAO. Crops. 2017. Available in: $\langle$ http://www.fao.org/faostat/en/\#data/QC $>$. Access in: $23 \mathrm{de}$ Abril de 2019.

FATZINGER, C. W.; ASHER, W. C. Mating Behavior and Evidence for a Sex Pheromone of Dioryctria abietella (Lepidoptera: Pyralidae (Phycitinae)). Annals of the 
Entomological Society of America v.64, n.3, p. 612-620, 1971. $\underline{10.1093 / \mathrm{aesa} / 64.3 .612}$

FERREIRA, J. M. S.; ARAÚJO, R. P. C.; SARRO, F. B. Insetos e ácaros, In: FERREIRA, J. M. S. (Ed.). Coco: fitossanidade. Brasília: Embrapa Informação Tecnológica; Aracaju: Embrapa Tabuleiros Costeiros, 2002. 136 p.

FONTES, H. R.; FERREIRA, J. M. S. A cultura do coqueiro. 1.ed. Brasília: Embrapa Informação Tecnológica, 2006. 101 p.

HABECK, D. H.; NICKERSON, J. C. Atheloca subrufella (Hulst), a pest of coconuts (Lepidoptera: Pyralidae: Phycitinae). Florida Department of Agriculture and Consumer Services, Division of Plant Industry, Entomology Circular, n.241, p. 1-2, 1982.

HEINRICH, C. American moths of the family Phycitinae. United States National Museum Bulletin, 207: viii, 581 pp. 1956. Available in:

<https://archive.org/stream/bulletinunited2071956unit\#page/82/ mode/2up>. Access in: 26 de Abril de 2019.

HODGES, R. W.; DOMINICK, T.; DAVIS, D. R.; FERGUSON, D. C.; FRANCLEMONT, J. G.; MONROE, E. G.; POWELL, J. A. Check List of the Lepidoptera of America North of Mexico. E. W. Classey Ltd. \& The Wedge Entomological Research Foundation, London. 1983, 284 p.

KIMBALL, C. P. The Lepidoptera of Florida. Florida Department of Agriculture and Consumer Services, Division of Plant Industry, Arthropods of Florida and Neighboring Land Areas v.1, p. 1-363. 1965.

LI, H. H.; RE, Y. D. Insect fauna of Henan (Lepidoptera: Pyraloidea). Beijing: Science Press, 2009. 440 p.

MOORE, D. Insects of palm flowers and fruits, In: HOWARD, F. W.; MOORE, D.; GIBLIN-DAVIS, R. M.; ABAD, R. G. (Ed), Insects on Palms. Wallingford: CAB International, 2001. $400 \mathrm{p}$.

NASCIMENTO, E. S.; AMBROGI, B. G.; PINTOZEVALLOS, D. M.; SOUSA-SOUTO, L. Age-dependent pattern of calling behavior in Atheloca subrufella (Hulst) (Lepidoptera: Phycitidae). Journal of Insect Behavior, v.29, n.2, p. 190-198, 2016. 10.1007/s10905-016-9552-6

PARRA-PEDRAZZOLI, A. L.; LEAL, W. S. Sexual Behavior of the Navel Orangeworm, Amyelois transitella (Walker) (Lepidoptera: Pyralidae). Neotropical Entomology v.35, n.6, p.769-774, 2006. 10.1590/S1519-566X2006000600008

SANDERS, C. J.; WEATHERSTON, J. Sex pheromone of the eastern spruce budworm (Lepidoptera: Tortricidae): optimum blend of trans- and cis-11-tetradecenal. The Canadian Entomologist, v.108, p. 1285-1290, 1976. $\underline{10.4039 / E n t 1081285-11}$
SHI, X. H.; MA, T.; ZHANG, S. N.; SUN, Z. H.; CHEN, X. Y.; WANG, C. L.; JIA, C. J.; LIANG, Y. C.; ZHU, Y.; HE, Y. R.; WEN, X. J. Calling and mating behavior of Diaphania angustalis (Lepidoptera: Crambidae). Journal of Economic Entomology, v.111, n.5, p. 2250-2254, 2018. $\underline{10.1093 / \text { jee/toy } 179}$

SILK, P. J.; EVELEIGH, E.; ROSCOE, L.; BURGESS, K.; WEATHERBY, S.; LECLAIR, G.; MAYO, P.; BROPHY, M. Unsaturated Cuticular Hydrocarbons Enhance Responses to Sex Pheromone in Spruce Budworm, Choristoneura fumiferana. Journal of Chemical Ecology, v.43, p. 753-762, 2017. $\underline{10.1007 / \mathrm{s} 10886-017-0871-7}$

SILK P. J.; TAN, S. H.; WIESNER, C. J.; ROSS, R. J.; LONERGAN, G. C. Sex pheromone chemistry of the eastern spruce budworm, Choristoneura fumiferana. Environmental Entomology, v.9, p. 640-644, 1980. 10.1093/ee/9.5.640 